Prof. Corneliu-Liviu POPESCU

\title{
Natura și regimul juridic ale acordurilor dintre Ministerul Afacerilor Interne și Patriarhia Română privind Sărbătorile Pascale din perioada stării de urgență
}

\section{The nature and legal regime of the agreements between the Ministry of Internal Affairs and the Romanian Patriarchate regarding the Easter Holidays during the state of emergency}

\section{Cuvinte cheie}

Stare de urgență. Sănătate publică. Serviciu religios. Ministerul Afacerilor Interne. Patriarhia Bisericii Ortodoxe Române. Contract administrativ.

\section{Key words}

State of siege. Public health. Religious service. Ministry of Internal Affairs. Patriarchate of the Orthodox Romanian Church. Administrative contract.

\section{Rezumat}

Acordurile semnate între Ministerul Afacerilor Interne și Patriarhia Bisericii Ortodoxe Române de stabilire a unor măsuri privind Sărbătorile Pascale din anul 2020, în timpul stării de urgență, privesc colaborarea dintre o autoritate publică și un cult religios privind serviciile religioase, în vederea exercitării libertății de religie. Deși nu urmăresc prestarea unui serviciu public, ci a unui serviciu privat, adică a serviciului religios, ele sunt contracte administrative, urmărind interesul public al apărării sănătății publice. De aceea, ele sunt contracte administrative nenumite și atipice.

\section{Abstract}

The agreements signed between the Ministry of Internal Affairs and the Patriarchate of the Romanian Orthodox Church to establish measures for the Easter Holidays in 2020, during the state of emergency, concern the collaboration between a public authority and a religious cult on religious services, in order to exercise freedom of religion. Although they don't aim at providing a public service, but at a private one, ie the religious service, they represent administrative contracts, pursuing the public interest of defending public health. Therefore, they 
should be considered unnamed and atypical administrative contracts.

1. Pe data de 14.04.2020 a fost semnat, între Ministrul Afacerilor Interne și Patriarhul Bisericii Ortodoxe Române, un acord de stabilire a unor măsuri privind Sărbătorile Pascale din anul 2020, în timpul stării de urgență ${ }^{1}$.

Ulterior, în urma criticilor publice exprimate de Președintele României, acest acord a fost modificat de părți printr-un acord semnat în ziua următoare ${ }^{2}$.

2. Obiectul acestui acord (modificat) îl reprezintă activitatea părților și colaborarea dintre părți privind serviciile religioase din perioada Sărbătorilor Pascale din anul 2020, adică în timpul stării de urgență, instituite prin Decretul Președintelui României nr. 195/2020³ și prelungite prin Decretul Președintelui României nr. 240/2020 .

3. În sine, existența unui astfel de acord este constituțională și convențională

Art. 29, "Libertatea conștiinței", alin. (5) din Constituție ${ }^{5}$ dispune: "Cultele religioase sunt autonome față de stat și se bucură de sprijinul acestuia, inclusiv prin înlesnirea asistenței religioase în armată, în spitale, în penitenciare, în azile și în orfelinate."

Constituția consacră un regim de colaborare între stat și cultele religioase, existând îndatorirea statului de a sprijini cultele religioase, enumerarea constituțională a formelor de sprijin fiind doar exemplificativă, iar nu exhaustivă.

În același timp, art. 9, "Libertatea de gândire, de conștiință și de religie", din Convenția europeană a drepturilor omului consacră inter alia libertatea de religie, care are atât o dimensiune internă (dreptul omului de a avea sau de a nu avea, în forul său interior, o credință religioasă și de a o schimba), cât și una externă (dreptul de manifestare a religiei, în public sau în privat, singur sau împreună cu alții, inclusiv dreptul de a nu-și manifesta religia). Dimensiunea internă a libertății de religie este un drept absolut, în timp ce dimensiunea sa externă (manifestarea religiei) este un drept condițional, putând suferi ingerințe, dacă sunt prevăzute de lege, dacă urmăresc un scop legitim și dacă sunt necesare într-o societate democratică.

Jurisprudența Curții Europene a Drepturilor Omului impune statelor nu doar obligația negativă de a nu încălca libertatea de religie, ci și obligații pozitive de a proteja exercitarea libertății de religie.

Sprijinul acordat Bisericii Ortodoxe Române de Ministerul Afacerilor Interne este, în sine, conform îndatoririi constituționale a statului de sprijinire a cultelor religioase și obligației convenționale de a lua măsuri pozitive pentru exercitarea 
libertății de religie.

4. Dacă afirmațiile publice ale Ministrului Afacerilor Interne sunt adevărate, încheierea acestui acord nu constituie o discriminare față de celelalte culte religioase și față de credincioșii acestora.

Astfel, Ministrul Afacerilor Interne a declarat public faptul că inițiativa acordului a aparținut Bisericii Ortodoxe Române și că, dacă orice alt cult religios ar fi solicitat același lucru, s-ar fi încheiat acorduri similare.

În acest mod, neutralitatea statului față de cultele religioase și tratare în mod egal de stat a cultelor religioase au fost respectate.

5. În opinia noastră, ca natură juridică, acest acord este un contract administrativ.

Contractele administrative sunt o creație pretoriană a Consiliului de Stat francez, curtea supremă a ordinului jurisdicțional administrativ. În absența unor norme juridice speciale (administrative), derogatorii de la dreptul comun (civil), judecătorul administrativ a constatat imposibilitatea aplicării integrale a regulilor de drept civil în raporturile în care este implicată administrația, întrucât trebuie să se țină seama de particularitățile decurgând din puterea publică și din misiunea de serviciu public. În acest mod a fost conturat, pe cale jurisprudențială (formalizată ulterior legislativ), regimul juridic al contractelor administrative.

Într-un contract administrativ cel puțin una dintre părți este o persoană de drept public, acționând în această calitate (adică în temeiul capacității de drept public, iar nu al celei de drept privat), pentru îndeplinirea unei misiuni de interes general (cum ar fi prestarea unui serviciu public, exploatarea bunurilor domeniului public etc.), în regim de putere publică, sub controlul judecătorului specializat (de contencios) administrativ.

Un contract administrativ are o parte regulamentară (impusă de contractantul persoană de drept public, conform normelor juridice în vigoare) și o parte consensuală (negociată și agreată de părți). Părțile contractului sunt egale la momentul încheierii contractului, fiind libere să decidă încheierea sau nu a contractului (ca în dreptul civil), în timp ce sub aspectul executării și încetării contractului egalitatea lor există doar pentru partea consensuală a contractului administrativ, în timp ce pentru partea reglementară există o poziție supraordonată a administrației parte în contract, care o poate modifica unilateral sau poate decide unilateral încetarea existenței contractului, dacă interesul public o cere.

6. Acordul dintre Ministerul Afacerilor Interne și Biserica Ortodoxă Română satisface pe numere mari criteriile doctrinale de calificare a sa drept un contract administrativ. 
Una dintre părțile acordului, Ministerul Afacerilor interne, este o persoană juridică de drept public, o autoritate administrativă, acționând în temeiul capacității sale de drept public (ca autoritate publică), iar nu al capacității de drept privat.

Obiectul contractului este satisfacerea interesului public, adică atât protecția sănătății publice în timpul stării de urgență determinate de pandemie, prin organizarea exercitării corespunzătoare a libertății de practicare a religiei, cât și însăși exercitarea libertății religioase.

Regimul juridic la care este supus acordul este unul exorbitant, de drept public (chiar "foarte" exorbitant - exprimare voită -, și anume un regim derogatoriu excepțional de stare de urgență).

7. Principala particularitate a acestui acord, calificat de noi drept un contract administrativ, este aceea că satisfacerea interesului public nu se face prin prestarea unui serviciu public de un particular (parte în contract), ci prin prestarea unui serviciu privat (religios) de administrație (parte în contract).

Este adevărat că în acord se prevede și asigurarea ordinii publice de Ministerul Afacerilor interne, dar aceasta este o atribuție a acestui minister, prestată direct de acesta și care nu este delegată contractual unor particulari, deci nu necesită încheierea vreunui contract administrativ pentru exercitarea ei.

Altfel spus, obiectul contractului nu este delegarea serviciului public de asigurare a ordinii publice către un particular și nici măcar asocierea administrației cu un particular în vederea prestării serviciului public de asigurare a ordinii publice.

Dimpotrivă, obiectul contractului administrativ este facilitarea de administrația contractantă (Ministerul Afacerilor Interne) a prestării, de cocontractantul particular (Biserica Ortodoxă Română), a serviciului religios, precum și prestarea directă de administrația contractantă a serviciului religios pentru cocontractantul particular.

În condițiile în care statul este separat de cultele religioase și nu există o religie oficială / de stat, serviciul religios este un serviciu privat, iar nu un serviciu public. Prestarea serviciului religios (ca serviciu privat) se face de cultele religioase (subiecte de drept privat, fără prerogative de putere publică), iar nu de stat, prin autoritățile publice ${ }^{6}$.

Cu toate acestea, rămâne ideea de satisfacere a interesului general, prin asigurarea interesului public al apărării sănătății publice în timp de pandemie, situație care a justificat instituirea, apoi prelungirea stării de urgență, precum și prin asigurarea interesului public al exercitării libertății religioase, ceea ce permite calificarea acordului ca fiind un contract administrativ.

8. Totuși, acest contract administrativ este unul nenumit și atipic. 
Faptul că nu este expres prevăzut de normele juridice în vigoare ca un contract administrativ nu împiedică existența și calificarea lui ca atare, fiind posibile contractele nenumite nu doar în cazul celor civile, ci și al contractelor administrative.

Acordul este în același timp un contract administrativ atipic, tocmai prin faptul că se urmărește prestarea de administrație a unui serviciu privat, iar nu de un particular a unui serviciu public.

În mod tipic, atunci când obiectul contractului administrativ este prestarea unui serviciu, serviciul respectiv este unul public. Sarcina prestării serviciului public revine administrației, care poate însă, printr-un contract administrativ, fie să delege unui particular prestarea serviciului public (contract de delegare de serviciu public), fie să asocieze un particular la prestarea în comun cu administrația a unui serviciu public (un parteneriat public-privat de gestionare a unui serviciu public).

De asemenea, aceste contracte administrative prin care se ajunge la prestarea unui serviciu public de un particular pot include și o componentă domenială, în sensul că se concesionează particularului bunuri domeniale necesare prestării serviciului public ori particularul este cel care construiește bunurile, care intră apoi în domeniul public, iar apoi sunt exploatate de particular fie prin concesiune, fie în parteneriat cu administrația.

Dimpotrivă, prin acest acord, administrația contractantă (Ministerul Afacerilor Interne) este cea care prestează serviciul (privat) religios, în numele, pe seama și în interesul particularului contractant (Biserica Ortodoxă Română), folosind bunurile, personalul și resursele financiare ale administrației.

9. Având atât specificitatea că nu particularul cocontractant prestează sau concură la prestarea unui serviciu public, ci administrația cocontractantă concură la prestarea de particular a unui serviciu privat (contractul fiind, totuși, unul administrativ, așa cum am arătat, întrucât asigură satisfacerea interesului general al apărării sănătății publice în timp de stare de urgență determinată de pandemie, precum și a interesului general al exercitării libertății religioase), cât și specificitatea că serviciul privat prestat de administrație este unul religios, se ridică problema posibilei obiecțiuni de conștiință pe care ar putea să o ridice membrii personalului administrației cocontractante față de sarcina de serviciu de a presta acest serviciu religios.

Este necesară separarea planurilor.

Pe de o parte, activitatea personalului Ministerului Afacerilor Interne de asigurare a ordinii publice și de asigurare a exercitării de terți a libertății de religie este prevăzută direct de actele normative, iar clauzele contractuale în acest sens sunt inutile. Cât timp exercitarea de terți a libertății de religie este legală, personalul Ministerului Afacerilor Interne este obligat să asigure exercitarea 
acestui drept de către respectivii titulari, indiferent de propriile convingeri religioase.

Altfel spus, un cadru al Ministerului Afacerilor Interne care este musulman sau ateu nu ar putea legal să refuze să participe la asigurarea ordinii publice și să asigure libera exercitare a libertății religioase de creștini, pe motiv că exercitarea de creștini a libertății lor religioase ar fi contrară propriilor convingeri.

Pe de altă parte însă, și acesta este obiectul principal al contractului administrativ dintre Ministerul Afacerilor Interne și Biserica Ortodoxă Română, personalul Ministerului Afacerilor Interne este obligat să presteze direct, personal, servicii religioase ortodoxe în numele și pe seama Bisericii Ortodoxe Române. Astfel, pct. 6 din Acordul din 15.04.2020, de modificare a Acordului din 14.04.2020, prevede: "În spitalele unde nu există preot de caritate, cadrele Ministerului Afacerilor Interne aflate în misiune în noaptea de Înviere vor distribui Sfânta Lumină acestor unități, precum și centrelor sociale și centrelor de carantină."

Pentru îndeplinirea personală a unui serviciu religios, care este un serviciu privat și care nu este prevăzută în sarcinile / atribuțiile /misiunile lor de serviciu, membrii personalului Ministerului Afacerilor Interne pot opune o obiecțiune de conștiință, adică pot refuza, pentru motive care țin de libertatea lor de conștiință și/sau de religie, să presteze acest serviciu religios. Este evident și de bun-simț că un musulman sau un ateu, chiar dacă face parte din Ministerul de Interne și se află în misiune, nu poate fi obligat să distribuie el personal Lumina Sfântă credincioșilor creștini ortodocși în noaptea de Înviere.

10. Fiind un contract administrativ (în care o persoană de drept public este parte contractantă), iar nu un act administrativ (act unilateral al unei autorități sau instituții publice ori al unei alte persoane de drept public), acordul trebuie să respecte absolut toate actele normative, cum ar fi legea organică privind regimul stării de urgență și al stării de asediu prevăzută de art. 73, "Categorii de legi", alin. (3) lit. g) din Constituție ${ }^{7}$, legea cultelor religioase, legile privind Ministerul Afacerilor interne, Poliția Română, Jandarmeria Română, Poliția de Frontieră Română, Poliția Locală, legea finanțelor publice, decretele Președintelui României de instituire și de prelungire a stării de urgență, ordonanțele militare și ordinele secretarului de stat, șef al Departamentului pentru Situații de Urgență din Ministerul Afacerilor Interne.

Nu se poate susține că, fiind semnat de Ministrul Afacerilor Interne, acordul ar avea o forță juridică egală cu a ordonanțelor militare (care sunt emise de Ministrul Afacerilor Interne) și, prin urmare, ar putea deroga de la ele.

Pe de o parte, ordonanța militară are o forță juridică superioare unui ordin al unui ministru, deoarece ele se emit de Ministrul Afacerilor Interne, dar necesită și acordul Primului-Ministru. Prin urmare, acordul, fiind semnat doar de Ministrul 
Afacerilor Interne, nu poate deroga de la o ordonanță militară, care este emisă de Ministrul Afacerilor Interne, dar are și acordul Primului-Ministru.

$\mathrm{Pe}$ de altă parte și mult mai important chiar, este de principiu că administrația, printr-un contract administrativ, nu poate deroga de la un act administrativ (act unilateral), chiar dacă ar fi emis de ea însăși (un act administrativ emis de chiar de administrația care este și parte în contractul administrativ) - a minori de un organ superior -, întrucât se încalcă principul nediscriminării.

Mai mult, în temeiul aceluiași principiu al nediscriminării, este de principiu că o administrație parte într-un contract administrativ este obligată să respecte, prin respectivul contract administrativ, actele administrative (acte unilaterale) provenind chiar de la autorități inferioare sieși și chiar subordonate (spre exemplu, un contract administrativ încheiat de Guvern trebuie să respecte un ordin al Ministrului Finanțelor Publice privind procedura de încheiere a contractelor administrative, altfel respectivul contract administrativ este nelegal). De aceea, acordul, chiar dacă este semnat de Ministrul Afacerilor Interne, pentru a fi legal trebuie să respecte, fiind un contract administrativ, inclusiv ordinele emise de secretarul de stat din Ministerul Afacerilor Interne, șef al Departamentului pentru Situații de Urgență (deși emitentul unui asemenea act administrativ este subordonat Ministrului Afacerilor Interne, semnatar al contractului administrativ).

11. Fiind un contract administrativ, cenzura legalității acordului dintre Ministerul Afacerilor Interne și Patriarhia Română este, în opinia noastră, de competența instanțelor de contencios administrativ, în timp ce un eventual litigiu privind executarea acordului ține de instanțele de drept comun, în temeiul art. 8 alin. (2) din Legea nr. 554/2004 a contenciosului administrativ .

Este adevărat că art. 2 lit. $c^{1}$ ) din această lege conține o enumerare (exemplificativă) a contractelor administrative - în care acordul nu se încadrează , urmată de o trimitere la legi speciale care pot reglementa alte contracte administrative, dar în opinia noastră acest lucru nu exclude nici existența contractelor administrative nenumite, nici competența de principiu a instanțelor de contencios administrativ de a cenzura legalitatea oricărui contract administrativ.

Nu formează obiectul analizei noastre chestiunea concretă, punctuală, a eventualei existențe a unor clauze contractuale nelegale.

12. Cenzura legalității acordului dintre Ministerul Afacerilor Interne și Patriarhia Română, în calitate de contract administrativ, de instanțele judecătorești de contencios administrativ, nu poate urmări decât respectarea, de acest contract administrativ, a normelor juridice ale statului român (inclusiv, așa cum am arătat, decretele de instituire și de prelungire a stării de urgență, 
ordonantele militare și ordinele secretarului de stat, sef al Departamentului pentru Situații de Urgență) ${ }^{9}$, iar nu și a Dreptului bisericesc ortodox (Dreptul canonic și celelalte norme ecleziastice).

Validitatea unui contract administrativ, chiar nenumit și atipic, se apreciază de instanța judecătorească exclusiv prin raportare la dreptul statal, iar nu (și) prin raportare la Dreptul bisericesc.

13. Conform însuși Dreptului bisericesc, autoritățile (Sfântul Sinod) și/sau instanțele (consistoriile) ecleziastice ar putea fi competente pentru a aprecia validitatea acordului din perspectiva Dreptului canonic și a întregului Drept bisericesc.

O eventuală necanonicitate sau o eventuală altă încălcare a Dreptului bisericesc, constatată de autoritățile sau instanțele ecleziastice, nu ar lipsi însă, prin ea însăși, acordul de efecte juridice, deoarece, în lipsa unei dispoziții normative sau a unei clauze contractuale exprese, un contract administrativ nu poate înceta prin voința unilaterală a particularului cocontractant (în cazul acordului, Biserica Ortodoxă Română).

Nu formează obiectul analizei noastre nici eventuala existență a unor clauze contractuale necanonice sau contrare în alt mod normelor ecleziastice.

14. În concluzie, în opinia noastră, acordul dintre Ministerul Afacerilor Interne și Biserica Ortodoxă Română este un contract administrativ, nenumit și atipic, prin care administrația contractantă este asociată direct, în mod excepțional, la prestarea de particularul cocontractant a serviciului privat al religiei, în temeiul obligației constituționale și convenționale a statului de a sprijini activitatea cultelor religioase, urmărind satisfacerea interesului public al asigurării sănătății publice în timpul stării de urgență determinate de pandemie și a interesului public al exercitării libertății religioase, în regim de putere publică, acord care trebuie să respecte toate actele normative în vigoare (inclusiv decretele de instituire și de prelungire a stării de urgență, ordonanțele militare și ordinele secretarului de stat, șef al Departamentului pentru Situații de Urgență), sub controlul de legalitate al instanțelor de contencios administrativ, în timp ce eventuala încălcare a Dreptului bisericesc ține exclusiv de competența autorităților și/sau instanțelor ecleziastice, fără ca o eventuală constatare de acestea a necanonicității sau a unei alte violări a normelor bisericești să ducă prin ea însăși la încetarea efectelor juridice ale acordului.

18.04.2020

Materialul a fost publicat în revista online a Facultăţii de Drept, $\underline{\text { AUBD-Forum }}$ Juridic nr. 1/2020. 


\footnotetext{
${ }^{1}$ Acord privind stabilirea unor măsuri cu ocazia Sărbătorilor Pascale în anul 2020, semnat de Ministrul Afacerilor Interne și de Patriarhul Bisericii Ortodoxe Române și înregistrat la Ministerul Afacerilor Interne sub nr. 12310/14.04.2020 și la Patriarhia Bisericii Ortodoxe Române sub nr. 4110/14.04.2020.

${ }^{2}$ Acord semnat de Ministrul Afacerilor Interne și de Patriarhul Bisericii Ortodoxe Române și înregistrat la Ministerul Afacerilor Interne sub nr. 12435/15.04.2020 și la Patriarhia Bisericii Ortodoxe Române sub nr. 4193/15.04.2020.

${ }^{3}$ Decretul Președintelui României nr. 195/2020 privind instituirea stării de urgență pe teritoriul României, publicat în Monitorul Oficial al României, partea I, nr. 212/16.03.2020.

${ }^{4}$ Decretul Președintelui României nr. 240/2020 privind prelungirea stării de urgență pe teritoriul României, publicat în Monitorul Oficial al României, partea I, nr. 311/14.04.2020.

${ }^{5}$ Republicată în Monitorul Oficial al României, partea I, nr. 767/31.10.2003.

${ }^{6}$ Este adevărat că există preoți militari, dar ei prestează serviciile religioase în calitate de preoți, iar nu în calitate de militari.

7 În concret, Ordonanța de urgență a Guvernului nr. 1/1999 privind regimul stării de asediu și regimul stării de urgență, publicată în Monitorul Oficial al României, partea I, nr. 22/21.01.1999.

${ }^{8}$ Publicată în Monitorul Oficial al României, partea I, nr. 1154/07.12.2004.

9 Evident, chestiunea este în realitate teoretică și iluzorie, iar nu reală și efectivă, întrucât Președintele României, prin decretele de instituire și de prelungire a stării de urgență, a suprimat practic funcționarea justiției pe durata stării de urgență, fără niciun temei constituțional sau legal.
} 